\title{
Sodium Ion Batteries using lonic Liquids as Electrolytes
}

$\operatorname{AUTHOR}(\mathrm{S})$ :

Hagiwara, Rika; Matsumoto, Kazuhiko; Hwang, Jinkwang; Nohira, Toshiyuki

\section{CITATION:}

Hagiwara, Rika ...[et al]. Sodium Ion Batteries using Ionic Liquids as Electrolytes. Chemical Record 2019, 19(4): 758-770

ISSUE DATE:

2019-04

URL:

http://hdl.handle.net/2433/240761

\section{RIGHT:}

This is the peer reviewed version of the following article: R. Hagiwara, K. Matsumoto, J. Hwang. T. Nohira, Chem. Rec 2019, 19, 758., which has been published in final form at https://doi.org/10.1002/tcr.201800119. This article may be used for non-commercial purposes in accordance with Wiley Terms and Conditions for Use of Self-Archived Versions.; The full-text file will be made open to the public on 1 April 2020 in accordance with publisher's 'Terms and Conditions for Self-Archiving'.; この論文は出版社版でありません。引用の際には出版社版をご確認ご利用ください。; This is not the published version. Please cite only the published version. 
Sodium ion batteries using ionic liquids as electrolytes

Rika Hagiwara, ${ }^{\left[{ }^{[a]}\right.}$ Kazuhiko Matsumoto, ${ }^{[a]}$ Jinkwang Hwang, ${ }^{[a]}$ and Toshiyuki Nohira ${ }^{[b]}$

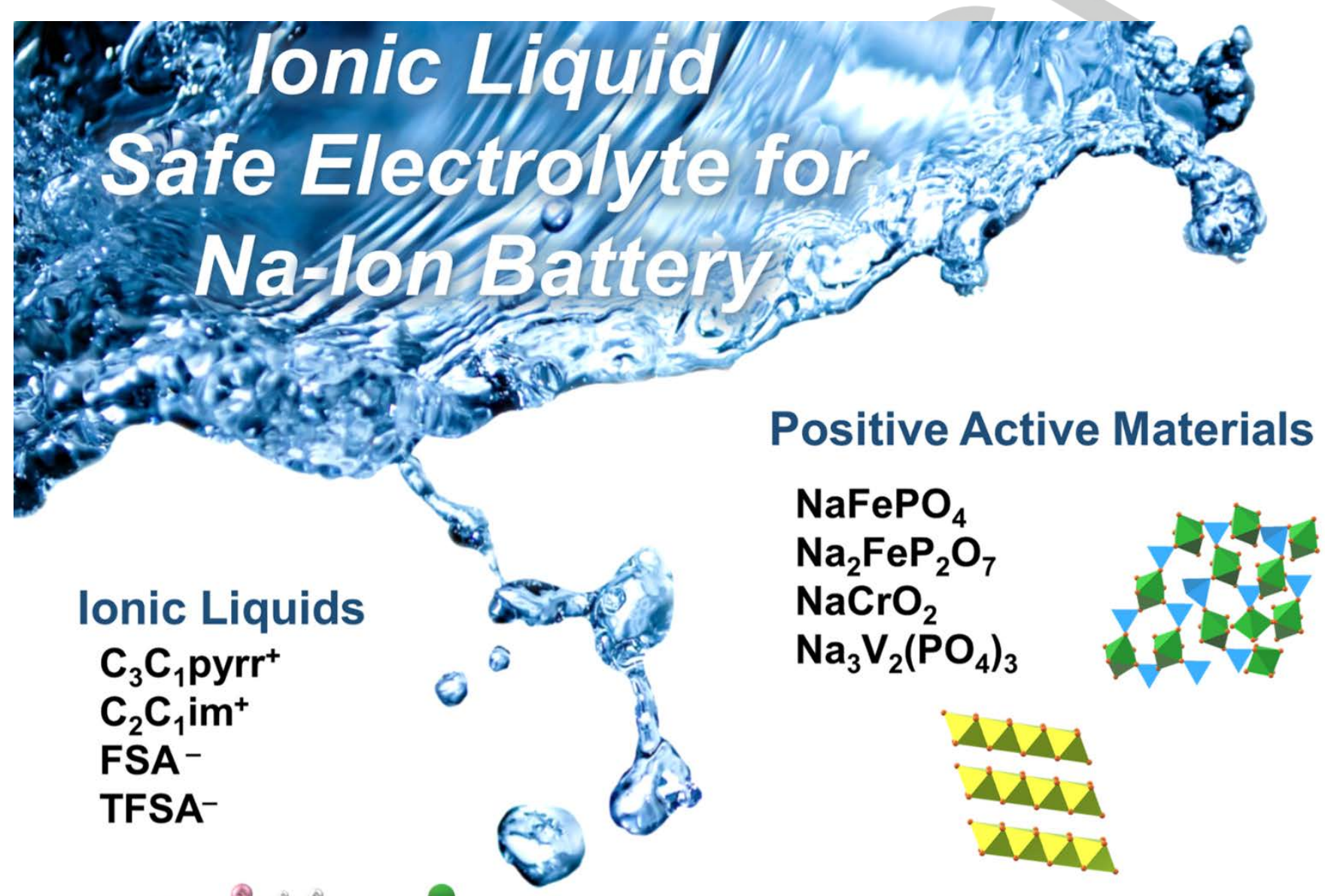

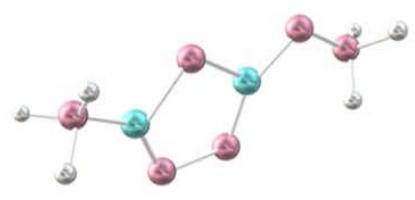
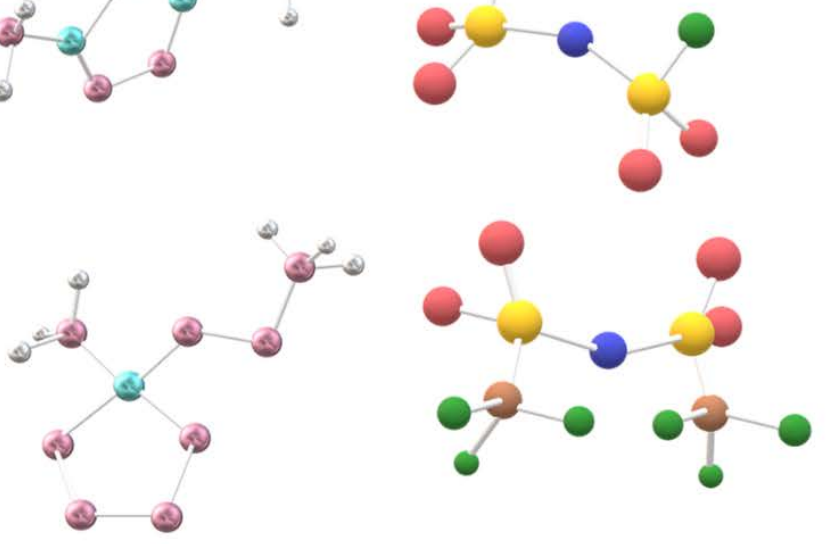

Negative Active Materials Hard Carbon Metal Alloy

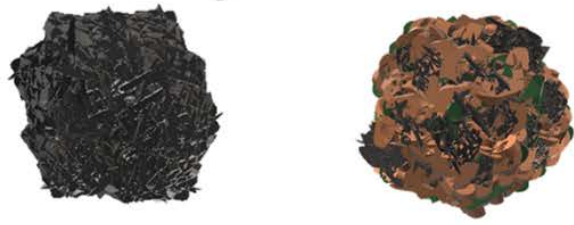




\begin{abstract}
Sodium ion batteries have been developed using ionic liquids as electrolytes. Sodium is superior to lithium as a raw material for mass production of large-scale batteries for energy storage due to its abundance and even distribution across the earth. Ionic liquids are non-volatile and non-flammable, which improved the safety of the batteries remarkably. In addition, operation temperatures were extended to higher values, improving the performance of the batteries by facilitating the reaction at the electrode and mass transfer. Binary systems of sodium and quaternary ammonium salts, such as 1-ethyl-3methylimidazolium and $N$-methyl- $N$-propylpyrrolidinium bis(fluorosulfonyl)amide, were employed as electrolytes for sodium ion batteries. A series of positive and negative electrode materials were examined to be combined with these ionic liquid electrolytes. A 27 Ah full cell was fabricated employing sodium chromite $\left(\mathrm{NaCrO}_{2}\right)$ and hard carbon as positive and negative electrode materials, respectively. The gravimetric energy density obtained for the battery was $75 \mathrm{Wh} \mathrm{kg}^{-1}$ and its volumetric energy density was $125 \mathrm{Wh} \mathrm{L}^{-1}$. The capacity retention after 500 cycles was $87 \%$. Further improvement of the cell performance and energy density is expected on development of suitable electrode materials and optimization of the cell design.
\end{abstract}

\section{Introduction}

In recent years, secondary batteries have not only been used in small electronic devices such as portable equipment but have also been intended for use in larger devices, including energy storage components of power systems and electric cars. ${ }^{[1]}$ Secondary batteries for energy storage are already commercially available in the form of NAS (sodium-sulfur) batteries that operate at temperatures of $300{ }^{\circ} \mathrm{C}$ or higher. NAS batteries are attractive because of their cycle characteristics and high durability as well as in terms of element strategy, as they are solely composed of naturally abundant elements. However, the $\beta$ "-alumina solid electrolyte used in such batteries is problematic with respect to safety, owing to its vulnerability to heat and physical shock caused by dendritic sodium. ${ }^{[1,2]}$ Thus, a different type of secondary battery, with improved safety and high energy density, is essential for small stationary devices and for vehicles.

Attempts have been made to use lithium secondary batteries for energy storage. However, lithium itself shows highly uneven regional distribution, and its long-term stable supply is not considered guaranteed ${ }^{[3]}$. Furthermore, these batteries have $\mathrm{LiCoO}_{2}$ positive electrodes, which contain the rare metal Co: therefore, from the standpoint of resource availability, these batteries are not suitable for use in large devices. At present, the supply problem is not significant but, in 2016, the market price of

[a] Prof. Dr. Rika Hagiwara, Prof. Dr. Kazuhiko Matsumoto, Jinkwang Hwang

Graduate School of Energy Science

Kyoto University

Yoshida-honmachi, Sakyo-ku, Kyoto 606-8501, Japan

hagiwara@energy.kyoto-u.ac.jp

[b] Prof. Dr. Toshiyuki Nohira

Institute of Advanced Energy

Kyoto University

Gokasho, Uji 611-0011, Japan lithium carbonate jumped to almost four times of that in the preceding year. Lithium secondary batteries are viewed as promising secondary batteries for electric cars, and it is expected that the supply of lithium resources may become unstable as electric cars become more popular. ${ }^{[1 \mathbf{1}, 1 \mathbf{1}, 4]}$ Based on this premise, sodium secondary batteries have been attracting attention as promising high-performance substitutes for lithium secondary batteries, and various works have been reported in this context ${ }^{[4 a, 4 b, 5]}$. There is a great wealth of sodium resources distributed throughout the world, including in the oceans, without the uneven regional distribution observed for lithium resources. Therefore, even if these batteries were used in the large quantities required by large devices, sodium would not generate unstable market prices.

Currently, organic solvents such as propylene carbonate (PC), ethylene carbonate (EC), diethyl carbonate (DEC), and ethyl methyl carbonate (DMC) with $\mathrm{Na}$ salts of $\mathrm{NaClO}_{4}$ and $\mathrm{NaPF}_{6}$ dissolved in them ${ }^{[5 \mathrm{~b}, 6]}$ are widely used as electrolytes in studies on sodium secondary batteries. Organic electrolytes have the advantage of being easy to handle and have superior properties around room temperature. On the other hand, there are safety hurdles that must be surpassed before they can be used in large devices, as organic solvents are volatile and flammable. ${ }^{[7]}$ In addition, the thermal stability of the solid-electrolyte interface (SEI) film that forms between the electrolyte and electrode is limited at around $60{ }^{\circ} \mathrm{C}$; therefore, the generation of heat becomes problematic in large devices, and dense packing of the battery modules becomes difficult.

Electrolytes for batteries in small electronic equipment must operate without a temperature control function, and so it is essential that these batteries operate stably from temperatures as low as possible to room temperature. However, batteries used for cars and energy storage, which are based on the premise of the presence of control devices (battery management systems) ${ }^{[2 a, 8]}$, including control of operation output and temperature, may be required to operate at temperatures above room temperature to elicit superior characteristics.

We have undertaken our investigation using ionic liquids (molten salts) with low melting points as electrolytes for safer, high-performance sodium secondary batteries. Ionic liquids are non-volatile, non-combustible, usable across a wide temperature range, and thermally and chemically stable, and have potential applications in various fields, including those involving chemical synthesis, vacuum technology, and tribology ${ }^{[9]}$. Even in the electrochemical field, previous research has investigated the use of ionic liquids as plating baths to plate base metals at ambient temperatures ${ }^{[10]}$. Recently, however, there has been a surge of interest in ionic liquids as electrolytes for secondary batteries ${ }^{[11]}$ In particular, we have investigated the advantages of the thermal stability of ionic liquids in secondary batteries for large devices, for which the operating temperature has been extended to the intermediate temperature range (up to around $150{ }^{\circ} \mathrm{C}$ ), and our current research focuses on the properties of batteries in this temperature range and potential new applications of such batteries. Such applications include attaining properties that cannot be reached at room temperature; taking advantage of the high ionic conductivity of electrolytes or electrode materials and achieving fast electrode kinetics characteristic of operation at intermediate temperatures; and being able to use electrode materials that were not previously applicable.

In this paper, we will introduce the properties of inorganicorganic hybrid ionic liquids and their use as ionic liquid electrolytes for sodium secondary batteries that operate at the room-to-intermediate temperature range. We also summarize the charge and discharge characteristics of a number of 
Rika Hagiwara is a Professor of Kyoto University. He received his B.S., M.S., and Ph.D. degrees from Kyoto University. From 1987 to 1991, he worked as a postdoctoral research fellow in the laboratory of Neil Bartlett at Lawrence Berkeley Laboratory, University of California, Berkeley. In 1991, he moved back to Kyoto University as an assistant professor and was promoted to associated professor in 1994, and full professor in 2005. He received the Molten Salt Committee Award in 2009 and the Academic Award in 2010 from the Electrochemical Society of Japan. His current research interests include the syntheses of fluorine compounds including ionic liquids and their derivatives as well as the study on their physicochemical properties as functional materials to be applied for energy storage and conversion.

Kazuhiko Matsumoto is an Associate Professor at Kyoto University. He studied chemistry at Kyoto University where he received his $\mathrm{PhD}$ degree in 2004 . $\mathrm{He}$ extended his research areas as a postdoc at Aichi Institute of Technology, at McMaster University, and at Kyoto University. He was appointed Assistant Professor in 2009 at Kyoto University and was promoted Associate Professor in 2015. He received the Molten Salt Prize for Young Researchers (Molten Salt Committee, ECSJ) in 2009, the Sano Award for Young Researchers (ECSJ) in 2013, and Commendation for Science and Technology by MEXT (Young Scientist Award) in 2017. His research interests are in inorganic and physical fluorine chemistry including structural characterization of new chemical species, synthesis and application of ionic liquids, and evaluation of electrolyte and electrode materials for electrochemical devices.

Jinkwang Hwang is currently pursuing his $\mathrm{PhD}$ with Professor Hagiwara in Graduate School of Energy Science, Kyoto University. He received his BSc degree in Chemistry from Nagoya University (2015), and received his Master 0 Energy Science from Kyoto University, (2017). His current research interest are synthesis and fabrication of positive electrode materials for $\mathrm{Li}$ - and Na-ion batteries and their electrochemical characteristic, and physical properties

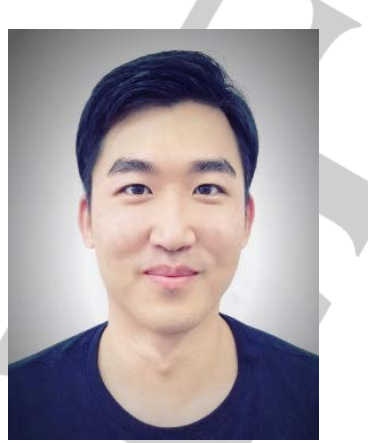

Toshiyuki Nohira is a Professor in the Institute of Advanced Energy of Kyoto University. He received a PhD degree in Engineering from Kyoto University in 1998. He was an Assistant Professor at Kyoto University from 1998 to 2006. He was promoted to Associate Professor in 2007, and to full Professor in 2015. In 2007, he was a visiting scientist at Massachusetts Institute of Technology for 9 months In 2009, He was awarded The Young Scientists' Prize, The Commendation for Science and Technology by the Minister of Education, Culture, Sports, Science and Technology of Japan. His current research focuses on electrochemical energy conversion and electrochemical material production utilizing molten salt and ionic liquid electrolytes. electrode materials that were evaluated for the first time in the intermediate temperature range using these ionic liquids.

\section{Characteristics of FSA-based ionic liquid in sodium secondary batteries for operation over a wide temperature range}

Table 1 Viscosity and ionic conductivity of $\mathrm{Na}[\mathrm{FSA}]-[\mathrm{Ocat}]$ [FSA] (30:70 in molar ratio, OCat: organic cation) ${ }^{[12]}$.

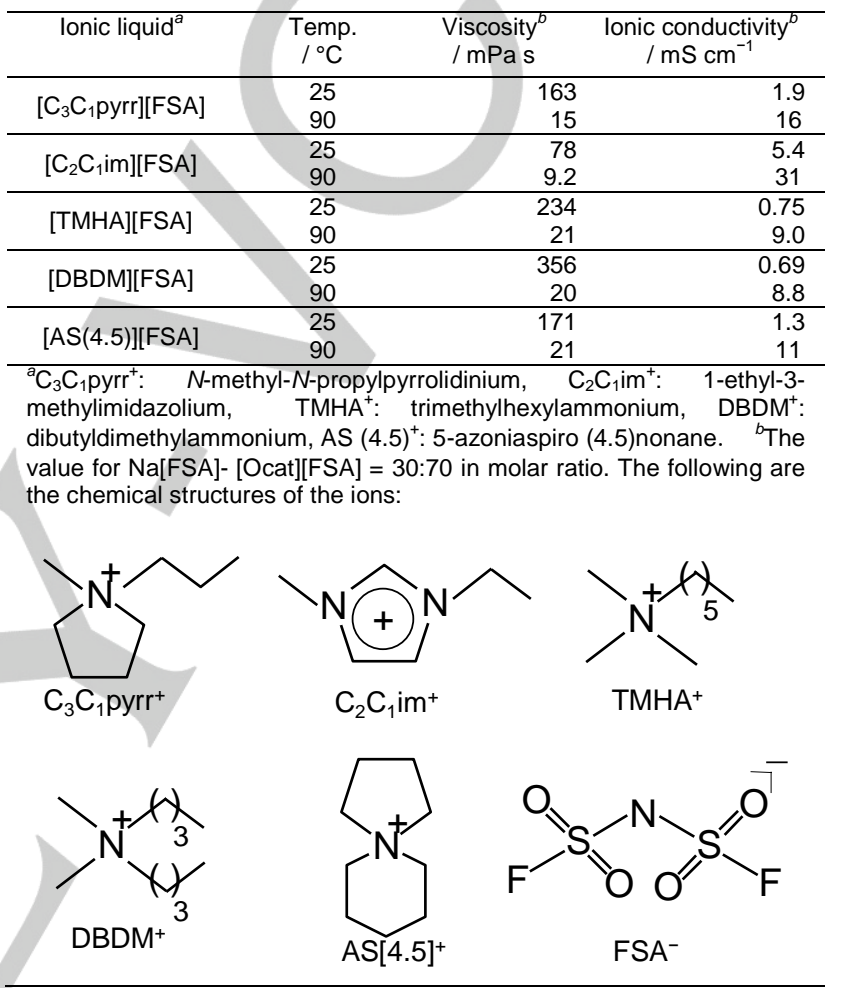

Here, we focus on $\mathrm{FSA}^{-}$(bis(fluorosulfonic)amide, $\mathrm{N}\left(\mathrm{SO}_{2} \mathrm{~F}\right)_{2}{ }^{-}$) as an ionic liquid anionic species for sodium secondary battery operation at intermediate temperatures, as it is an ionic liquid with a low melting point, high ionic conductivity, and a wide potential window. It is also inorganic; therefore, it can be produced relatively cheaply in large quantities. Currently, combinations of cations such as $\mathrm{C}_{2} \mathrm{C}_{1} \mathrm{im}^{+}, \mathrm{C}_{3} \mathrm{C}_{1}$ pyrr ${ }^{+}$, TMHA ${ }^{+}$, $\mathrm{DBDM}^{+}$, and AS $(4.5)^{+}$(see Table 1 for definitions of the abbreviations) are being investigated for use with the FSA anion [12]. Table 1 shows the viscosities and ionic conductivities of typical compositions of these ionic liquids. Phase diagrams for $\mathrm{Na}[\mathrm{FSA}]-\left[\mathrm{C}_{3} \mathrm{C}_{1}\right.$ pyrr][FSA] ${ }^{[12 \mathrm{a}]}$ and $\mathrm{Na}[\mathrm{FSA}]-\left[\mathrm{C}_{2} \mathrm{C}_{1}\right.$ im] [FSA] ${ }^{[12 \mathrm{~b}]}$ are shown in Figure 1 as examples. The liquid temperatures of all organic cations could be reduced by combining the cations with $\mathrm{Na}[\mathrm{FSA}]$ and, depending on the composition, these ionic liquids have liquid phases across a wide temperature range, above and below room temperature. Imidazolium showed low viscosity and the highest ionic conductivity, with a value of 5.4 $\mathrm{mS} \mathrm{cm}{ }^{-1}$ using an $\mathrm{Na}[\mathrm{FSA}]-\left[\mathrm{C}_{2} \mathrm{C}_{1}\right.$ im] $[\mathrm{FSA}]=30: 70$ (molar ratio) composition at $25{ }^{\circ} \mathrm{C}$, which is comparable to that of an organic electrolyte system (for example, the ionic conductivity of $\mathrm{NaClO}_{4}-\mathrm{PC}(1 \mathrm{M})$ at $25{ }^{\circ} \mathrm{C}$ is $\left.5.2 \mathrm{mS} \mathrm{cm}^{-1}{ }^{[13]}\right)$. As mentioned previously, the ionic conductivity increased with increasing temperature, reaching $31 \mathrm{mS} \mathrm{cm}^{-1}$ at $90{ }^{\circ} \mathrm{C}$. This value is 
Table 2 Reactivity of ionic liquids with sodium metals examined by visual observation and UV-VIS spectroscopy ${ }^{[16]}$.

\begin{tabular}{|c|c|c|c|c|c|c|c|}
\hline Sample & A & B & $\mathrm{C}$ & D & E & $\mathrm{F}$ & G \\
\hline $\mathrm{C}_{2} \mathrm{C}_{1} \mathrm{im}^{+}$ & $\begin{array}{l}\mathrm{FSA}^{-} \\
100 \%\end{array}$ & $\begin{array}{l}\text { TFSA }^{-} \\
100 \%\end{array}$ & $\begin{array}{l}\mathrm{FSA}^{-} \\
90 \%\end{array}$ & $\begin{array}{c}\text { TFSA }^{-} \\
90 \%\end{array}$ & $\begin{array}{l}\mathrm{FSA}^{-} \\
90 \%\end{array}$ & $\begin{array}{c}\text { TFSA }^{-} \\
90 \%\end{array}$ & $\begin{array}{c}\text { TFSA }^{-} \\
99 \%\end{array}$ \\
\hline $\mathrm{Na}^{+}$ & - & - & $\begin{array}{c}\mathrm{FSA}^{-} \\
10 \%\end{array}$ & $\begin{array}{c}\text { TFSA }^{-} \\
10 \%\end{array}$ & $\begin{array}{c}\text { TFSA }^{-} \\
10 \%\end{array}$ & $\begin{array}{c}\mathrm{FSA}^{-} \\
10 \%\end{array}$ & $\begin{array}{c}\mathrm{FSA}^{-} \\
1 \%\end{array}$ \\
\hline Color change & none & distinct & none & distinct & none & none & faint \\
\hline Change in UV-VIS spectrum & little & prominent & none & prominent & none & none & little \\
\hline
\end{tabular}

(a)

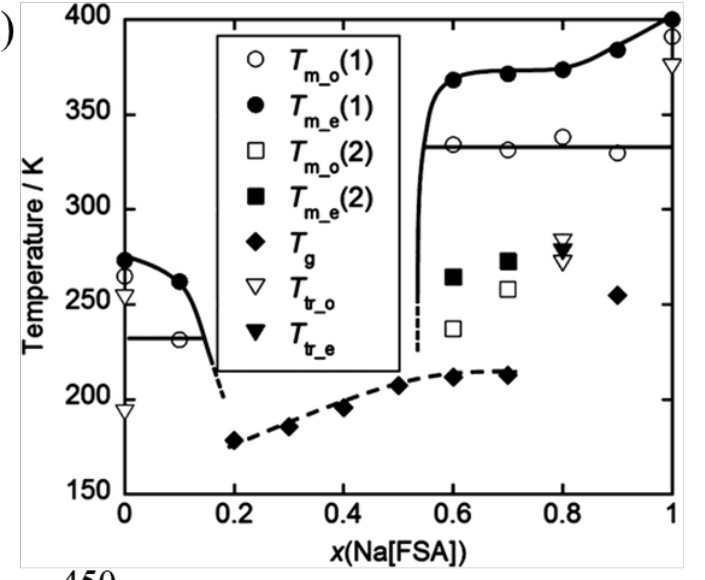

(b)

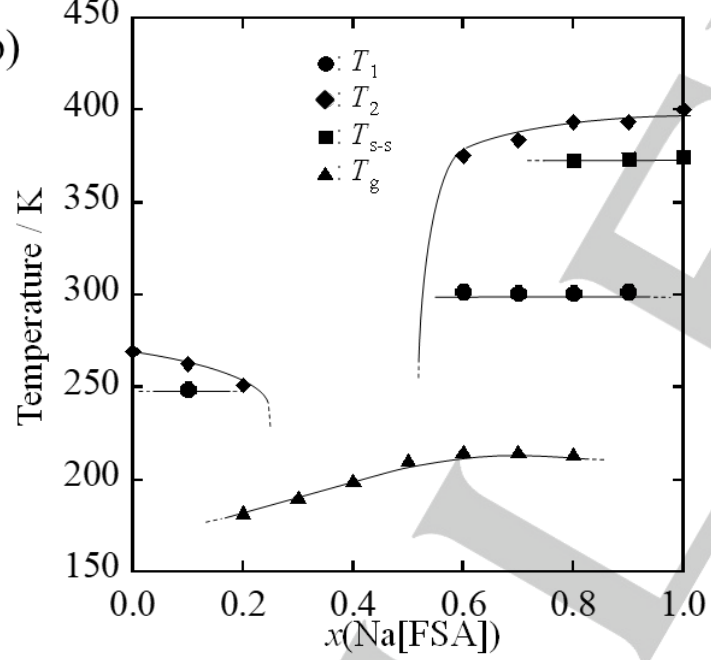

Figure 1 Binary phase diagrams, (a) $\mathrm{Na}[\mathrm{FSA}]-\left[\mathrm{C}_{3} \mathrm{C}_{1}\right.$ pyrr][FSA] ${ }^{[12 a]} . T_{\mathrm{m}}$ 。: Starting point of melting, $T_{\mathrm{m}} \mathrm{e}$ : End point of melting, $T_{g}$ : Glass transition point $T_{\text {tr_o }}$ : Starting point of solid-solid phase transition, $T_{\text {tr_e }}$ : End point of solid-solid phase transition. (b) $\mathrm{Na}[\mathrm{FSA}]-\left[\mathrm{C}_{2} \mathrm{C}_{1}\right.$ im] $[\mathrm{FSA}]^{[12 \mathrm{~b}]} \cdot T_{1}$ : Starting point of melting, $T_{2}$ : End point of melting, $T_{\mathrm{s}-\mathrm{s}}$ : Solid-solid phase transition point, $T_{g}$ : Glass transition point

sufficiently high, even when compared with corresponding values for organic solvent electrolytes at room temperature, which is a significant advantage for intermediate-temperature operation. The temperature dependence of the ionic conductivities and viscosities of the ionic liquids listed in Table 1 are shown in Figure 2. As can be seen in the Arrhenius plot, the viscosity graph (a) shows a concave shaped, while the ionic conductivity graph (b) forms a convex shaped. Thus, this ionic liquid does not fit the Arrhenius equation; instead, it fits (a) $10^{4}$

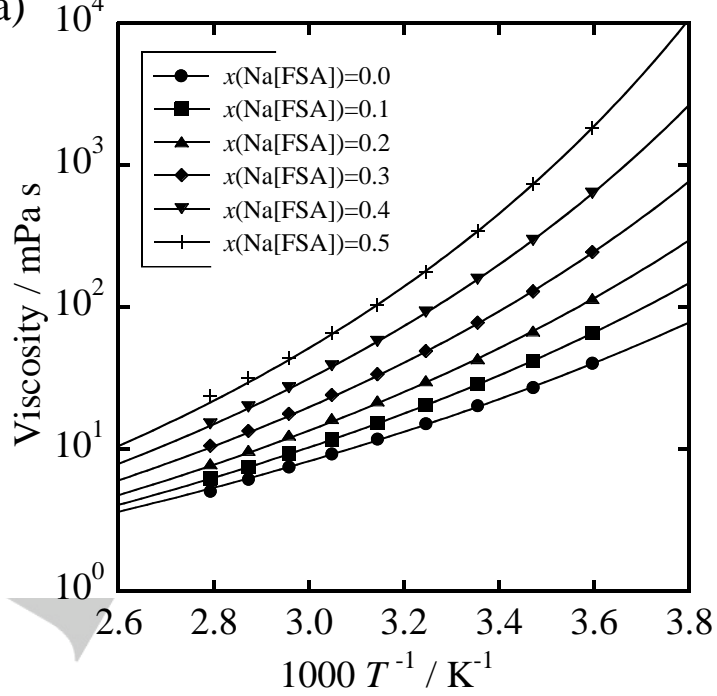

(b)

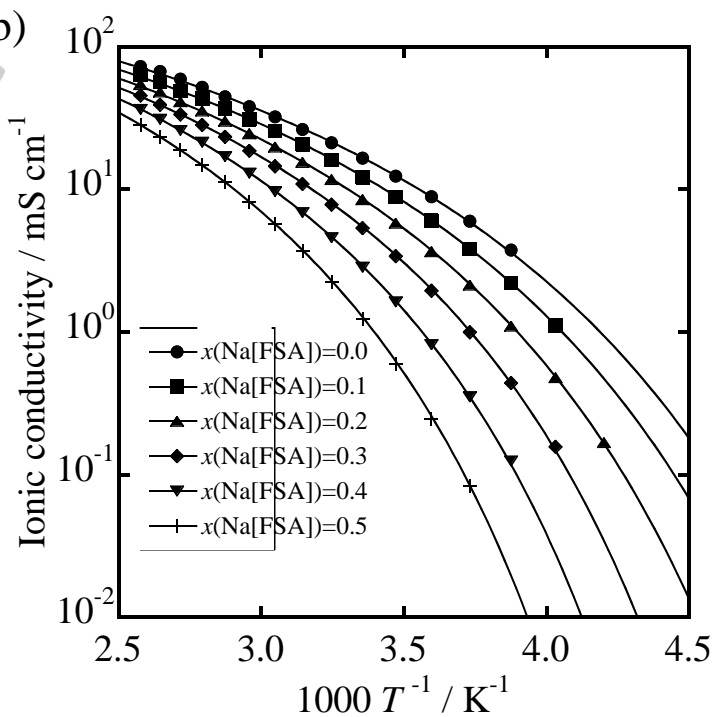

Figure 2 Temperature dependence of (a) viscosity and (b) ionic conductivity of $\mathrm{Na}[\mathrm{FSA}]-\left[\mathrm{C}_{2} \mathrm{C}_{1}\right.$ im] [FSA] binary ionic liquid electrolytes ${ }^{[12 \mathrm{~b}]}$.

equations (1) and (2), the Vogel-Tamman-Fulcher (VTF) equations $(\eta(T)$ represents viscosity and $\sigma(T)$ represents ionic conductivity) ${ }^{[14]}$; where $A_{\eta}, A_{\sigma}, B_{\eta}, B_{\sigma}, T_{0 \eta}$, and $T_{0 \sigma}$ are fitting parameters. $A$ and $B$ parameters are related to the carrier number and slope of the Arrhenius plot at a certain temperature, respectively. The last two parameters, $T_{0 \eta}$ and $T_{0 \sigma}$, are so-called ideal glass-transition temperatures. 


$$
\begin{aligned}
& \eta(T)=A_{\eta} \sqrt{T} \exp \left(\frac{B_{\eta}}{T-T_{0 \eta}}\right) \\
& \sigma(T)=\frac{A_{\sigma}}{\sqrt{T}} \exp \left(-\frac{B_{\sigma}}{T-T_{0 \sigma}}\right)
\end{aligned}
$$

Figure 3 shows a cyclic voltammogram from which the cathode limit using copper electrodes and the anode limit using glassy carbon and aluminum electrodes were determined in $\mathrm{Na}[\mathrm{FSA}]-\left[\mathrm{C}_{2} \mathrm{C}_{1} \mathrm{im}\right]$ [FSA] (30:70 molar ratio) at room temperature [12b]. The anode limit was approximately $5.2 \mathrm{~V}$ vs. $\mathrm{Na}^{+} / \mathrm{Na}$ on the glassy carbon electrode, but no large oxidation current was observed in this potential range on the aluminum electrode, which suggests that the more cost-effective aluminum (compared to copper) can be used as a positive electrode current collector for sodium secondary batteries.

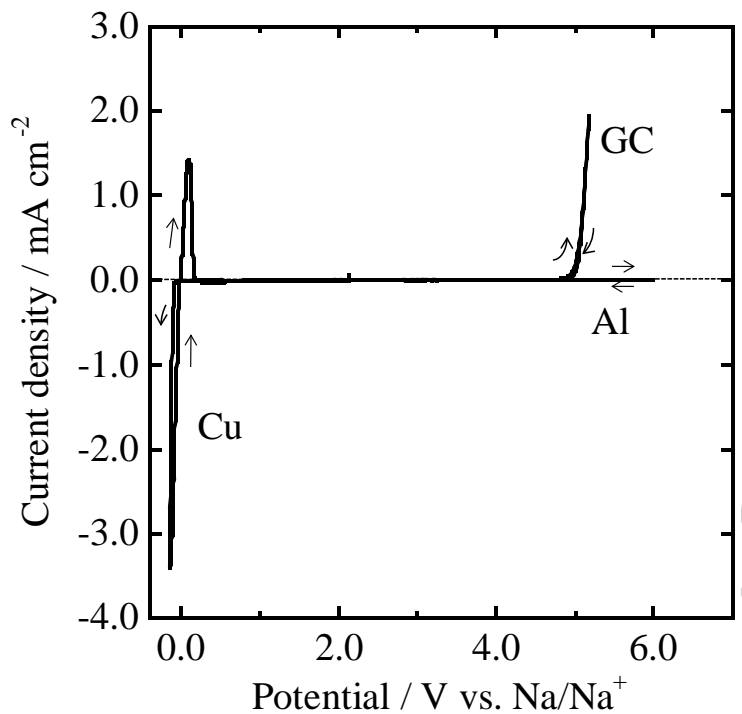

Figure 3 Cyclic voltammogram of $\mathrm{Na}[\mathrm{FSA}]-\left[\mathrm{C}_{2} \mathrm{C}_{1} \mathrm{im}\right][\mathrm{FSA}]$ (30:70 (in molar ratio)) ionic liquid. Temperature: $25^{\circ} \mathrm{C}$. Scan rate: $5 \mathrm{mV} \mathrm{s}^{-1[12 \mathrm{~b}]}$

Lithium-based ionic liquids containing $\mathrm{FSA}^{-}$are comparatively stable in terms of reduction, and it has been reported that $\mathrm{Li}^{+}$can be inserted into graphite ${ }^{[15]}$. To investigate the reduction stability of sodium-based ionic liquids, the reactivity of an FSA-based ionic liquid and a TFSA-based ionic liquid with sodium metal have been compared ${ }^{[16]}$. In this study, $\mathrm{Na}$ [FSA] and $\mathrm{Na}$ [TFSA] were used as sodium salts, $\left[\mathrm{C}_{2} \mathrm{C}_{1}\right.$ im] [FSA] and $\left[\mathrm{C}_{2} \mathrm{C}_{1}\right.$ im] [TFSA] were used as organic ionic liquids, and (as shown in Table 2) sodium metal was immersed in the ionic liquids obtained by mixing a $\mathrm{Na}$ and an $\left[\mathrm{C}_{2} \mathrm{C}_{1} \mathrm{im}\right]$ salt in arbitrary ratios. Based on the visible color changes and the ultraviolet and visible absorption spectrum changes, we found that the presence of even a minute amount of $\mathrm{FSA}^{-}$profoundly increased the stability of sodium metal in the ionic liquid. Differences in stability were seen depending on the presence of $\mathrm{Na}^{+}$, and organic ionic liquids containing $\mathrm{Na}^{+}$salts were more stable than organic ionic liquids alone. Based on the results of analysis using the electrochemical impedance method, we found that, in the TFSAbased ionic liquids, the reaction between the ionic liquid and sodium metal progressed steadily over a long period, in contrast to the case involving FSA-based ionic liquids, in which the reaction became severely delayed after the initial stages. These variations were thought to be due to differences in the stability and density of the film that formed on the surface of the sodium metal, which was consistent with the results of a previous analysis on surface film ${ }^{[17]}$. When sodium metal flakes were immersed in a TFSA-based ionic liquid for 12 months, the flakes became a completely transparent film. From this, we ascertained that the reaction between the TFSA-based ionic liquid and sodium metal progressed until the end.

There are binary mixtures of $\mathrm{Na}[\mathrm{FSA}]-\mathrm{K}[\mathrm{FSA}]$ (melting point $61^{\circ} \mathrm{C}$ ) that are inorganic ionic liquids, and they can be used as stable electrolytes at temperatures close to $140{ }^{\circ} \mathrm{C}$, which is the thermal decomposition temperature of $\mathrm{Na}\left[\mathrm{FSA}{ }^{[18]}\right.$. We are expecting future developments of this technology, as this inorganic ionic liquid demonstrates superior characteristics for the battery exclusively operated at intermediate temperatures.

\section{Charge and discharge behaviour of electrode materials in FSA-based ionic liquids at intermediate temperatures}

To date, $\mathrm{NaCrO}_{2}{ }^{[19]}, \mathrm{Na}_{2} \mathrm{FeP}_{2} \mathrm{O}_{7}{ }^{[20]}, \mathrm{Na}_{156} \mathrm{Fe}_{122} \mathrm{P}_{2} \mathrm{O}_{7}$ [21] $\mathrm{NaVOPO}_{4}{ }^{[22]}, \mathrm{NaMnSiO}_{4}{ }^{[23]}, \mathrm{Na}_{2 / 3} \mathrm{Fe}_{1 / 3} \mathrm{Mn}_{2 / 3} \mathrm{O}_{2}{ }^{[24]}, \mathrm{NaFePO}_{4}{ }^{[25]}$ and $\mathrm{Na}_{3} \mathrm{~V}_{2}\left(\mathrm{PO}_{4}\right)_{3}{ }^{[26]}$ have been investigated as positive electrode active materials for sodium secondary batteries using FSA-based ionic liquids as electrolytes. Among these pyrophosphate-based materials, using the plentiful resource of iron, are superior from an elemental strategy perspective. Also, vanadium, manganese, and chromium are less abundant than iron, but more so than cobalt ${ }^{[4 \mathrm{~b}]}$ which is currently used for lithium ion batteries. It should be noted that trivalent chromium is not toxic unlike the case of hexavalent chromium.

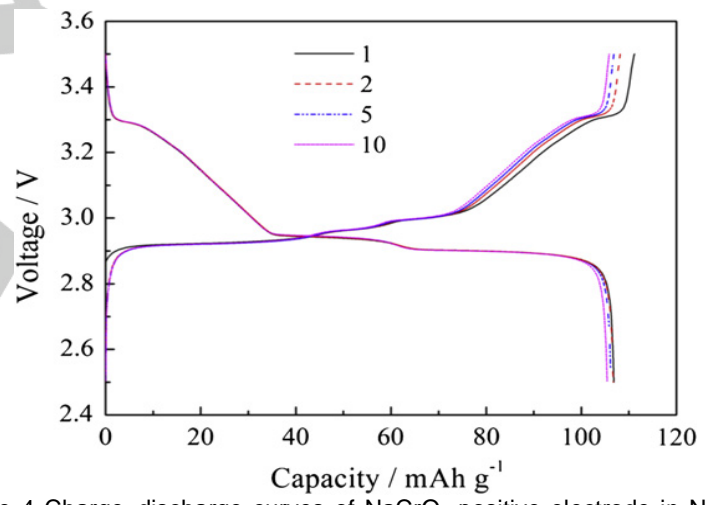

Figure 4 Charge-discharge curves of $\mathrm{NaCrO}_{2}$ positive electrode in $\mathrm{Na}[\mathrm{FSA}$ $\left[\mathrm{C}_{3} \mathrm{C}_{1}\right.$ pyrr][FSA] (20:80 in molar ratio) ${ }^{[19 \mathrm{c}]}$. Rate: $20 \mathrm{~mA} \mathrm{~g}^{-1}$. Cutoff voltages: 2.5-3.5 V Cycle \#: 1, 2, 5, 10

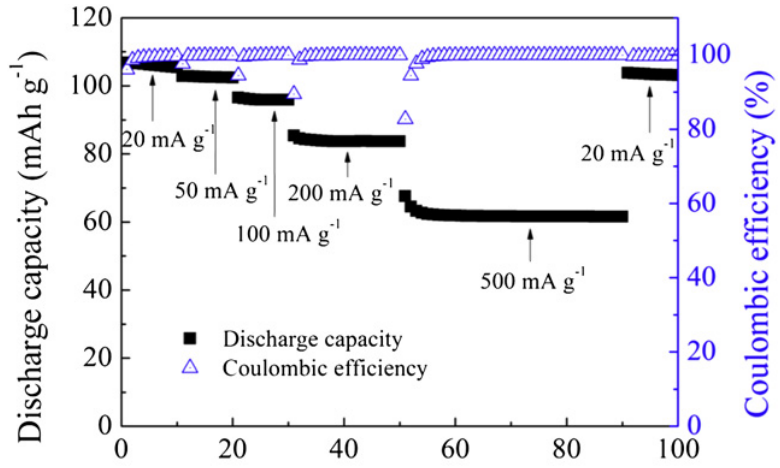

Cycle number

Figure 5 Discharge capacity and coulombic efficiency for $\mathrm{Na} / \mathrm{NaFSA}-\mathrm{C}_{3} \mathrm{C}_{1}$ pyrFSA $/ \mathrm{NaCrO}_{2}$ cell at $353 \mathrm{~K}{ }^{[19 \mathrm{c}]}$. Charge-discharge rates: $20,50,100,200,500$, and $20 \mathrm{~mA} \mathrm{~g}^{-1}$. Cut-off voltages: $2.5-3.5 \mathrm{~V}$. 


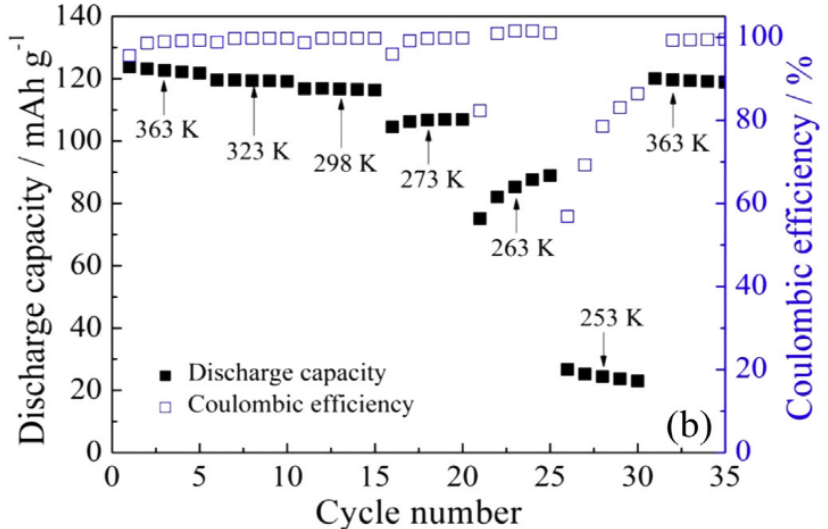

Figure 6 Discharge capacities and coulombic efficiency of a $\mathrm{Na} / \mathrm{Na}[\mathrm{FSA}]-$ $\left[\mathrm{C}_{3} \mathrm{C}_{1}\right.$ pyrr][FSA $] / \mathrm{NaCrO}_{2}$ cell with $25 \mathrm{~mol} \% \mathrm{Na}[\mathrm{FSA}]$ at 253-363 $\mathrm{K}$ : Chargedischarge rate: $20 \mathrm{~mA} \mathrm{~g}^{-1}$. Cut-off voltages: $2.5 \sim 3.5 \mathrm{~V}^{[19 \mathrm{~d}]}$.

Figure 4 shows the charge and discharge curves of $\mathrm{NaCrO}_{2}$ positive electrodes with $\mathrm{Na}[\mathrm{FSA}]-\left[\mathrm{C}_{3} \mathrm{C}_{1}\right.$ pyrr] [FSA] (20:80 molar ratio) ionic liquids as electrolytes ${ }^{[19 c]}$. The experiment was performed using coin cells, with sodium metal as the negative electrode, over a voltage range of $2.5-3.5 \mathrm{~V} . \mathrm{NaCrO}_{2}$ is a layered oxide, which has been used in sodium secondary batteries with a theoretical capacity of $125 \mathrm{mAh} \mathrm{g}{ }^{-1}$ in a $0.5-$ electron reaction ${ }^{[27]}$. The interlayer $\mathrm{Na}^{+}$decreases as the charge progresses, and the reaction progresses in a homogeneous phase; however, the coordination structure of the oxygen surrounding the $\mathrm{Na}^{+}$changes from an octahedron to a regular trigonal prism, and the structure changes from a rhombohedral crystal system to a monoclinic crystal system owing to JahnTeller distortion $[27 a, 27 c]$. There are four potential plateaus at around $2.90,2.95,3.00$, and $3.30 \mathrm{~V}$. The capacity of $\mathrm{NaCrO}_{2}$ corresponds to approximately half the frequent of sodium $\left(\mathrm{Na}_{x} \mathrm{CrO}_{2}, 0.5<x<1.0\right)$. In $\mathrm{NaCrO}_{2}, \mathrm{CrO}_{2}$ takes $\mathrm{CdCl}_{2}$ structure. $\mathrm{Na}$ ions take octahedral sites coordinated by six oxygen atoms between the two adjacent $\mathrm{CrO}_{2}$ layers. The space group of this structure is $\mathrm{R}-3 \mathrm{~m}$ (Phase I). The $\mathrm{d}$ orbitals of $\mathrm{Cr}$ in an octahedral crystal field degenerates to $e_{g}$ and $t_{2 g}$. The original electron configuration of trivalent $\mathrm{Cr}$ is $\left(t_{2 g}\right)^{3}$ where three degenerated $\mathrm{d}$ orbitals $\left(d_{x y}, d_{y z}, d_{x z}\right)$ are singly occupied by three electrons. As the desodiation proceeds in the charge process of $\mathrm{NaCrO}_{2}$, oxidation state of chromium changes from trivalent to tetravalent. Along with the oxidation, Jahn-Teller distortion of oxide ion arrangement around $\mathrm{Cr}$ atom from $O_{h}$ to $D_{4 h}$ occurs so that the $t_{2 g}$ orbitals generates to $b_{g}$ and $e_{g}$, to lower the energy of the latter two degenerated orbitals respectively occupied by one $\mathrm{d}$ electron. The distortion causes the deformation of crystal lattice to that with the s.g. of $\mathrm{C} 2 / \mathrm{m}$ (Phase II). The third phase transition is reported to occur by the in-plane ordering of $\mathrm{Na}$ ion in the oxide gallery (Phase III). The 4th phase appears when the desodiation proceeds to the middle of the full desodiation $(x \sim 0.75)$. In this phase, due to the slide of the adjacent two $\mathrm{CrO}_{2}$ layer, the coordination of oxygens around $\mathrm{Na}$ changes to trigonal prismatic arrangement (Phase IV). The final phase transition occurs by the ordering of $\mathrm{Na}$ ion in the oxide gallery again (Phase V). So five phases exist as a total. The potential plateaus appear at around $2.902 .95,3.00$, and $3.30 \mathrm{~V}$ as results of the two phase reaction of Phase I and II, II and III, III and IV and IV and $\mathrm{V}$, respectively ${ }^{[27 \mathrm{c}]}$. On discharge, the $\mathrm{Na}+$ ions are inserted back between the layers, resulting in reversible structural change and reverting to their original form. At $80^{\circ} \mathrm{C}$, at a charge and discharge rate of $20 \mathrm{mAh} \mathrm{g}^{-1}$, we found that the first cycle discharge capacity was $106 \mathrm{mAh} \mathrm{g}^{-1}$, and the coulombic

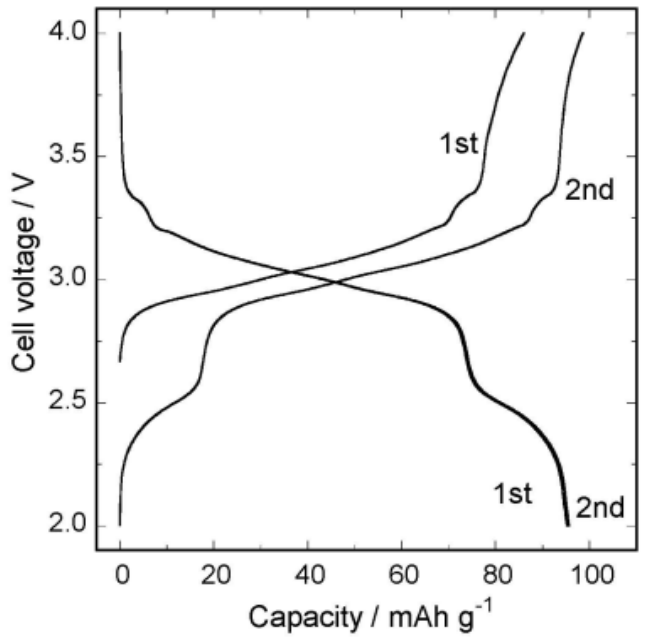

Figure 7 Charge-discharge curve of the $\mathrm{Na}_{2} \mathrm{FeP}_{2} \mathrm{O}_{7}$ positive electrode in $\mathrm{Na}[\mathrm{FSA}]-\left[\mathrm{C}_{2} \mathrm{C}_{1}\right.$ im] $][\mathrm{FSA}]\left(30: 70\right.$ in molar ratio) ${ }^{[20 \mathrm{c}]}$. Charge-discharge rate: 10 $\mathrm{mA} \mathrm{g}^{-1}$. Cutoff voltage: $2.0-4.0 \mathrm{~V}$. Temperature: $90^{\circ} \mathrm{C}$ ).

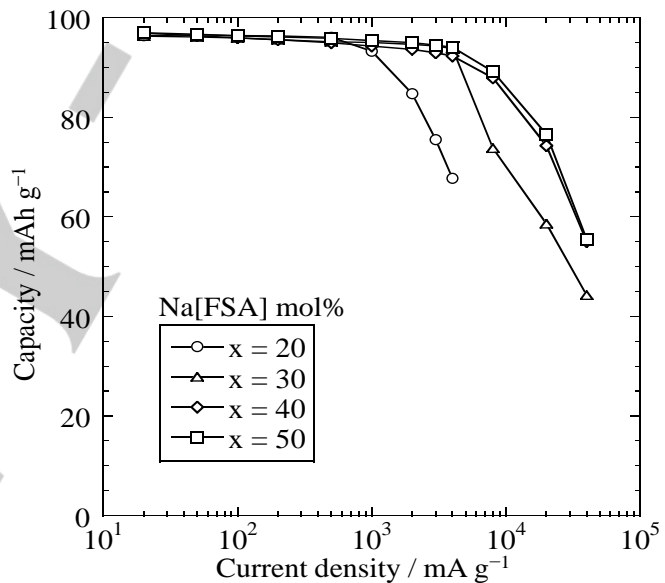

Figure 8 Rate capability of the discharge of $\mathrm{Na}_{2} \mathrm{FeP}_{2} \mathrm{O}_{7}$ positive electrode in $\mathrm{Na}[\mathrm{FSA}]-\left[\mathrm{C}_{2} \mathrm{C}_{1}\right.$ im] $[\mathrm{FSA}]\left(30: 70\right.$ in molar ratio) ${ }^{[20 \mathrm{c}]}$. Charge rate: $10 \mathrm{~mA} \mathrm{~g}^{-1}$ Cutoff voltage: $2.0-4.0 \mathrm{~V}$. Temperature: $90^{\circ} \mathrm{C}$

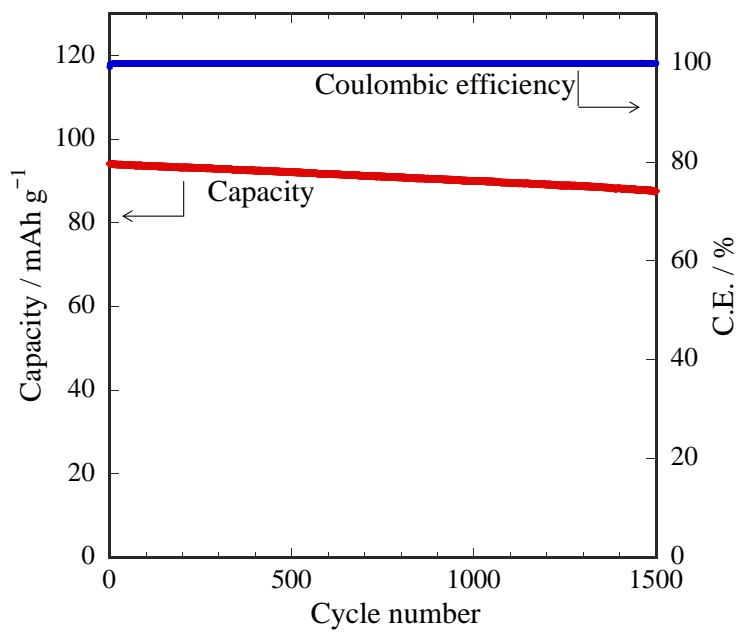

Figure 9 Cycle performance of $\mathrm{Na}_{2} \mathrm{FeP}_{2} \mathrm{O}_{7}$ positive electrode in $\mathrm{Na}$ [FSA] $\left[\mathrm{C}_{2} \mathrm{C}_{1}\right.$ im] [FSA] (30:70 in molar ratio) ${ }^{[20 \mathrm{c}]}$. Charge-discharge rate: $1000 \mathrm{~mA} \mathrm{~g}^{-1}$ Cutoff voltages: $2.0-4.0 \mathrm{~V}$. Temperature: $90^{\circ} \mathrm{C}$. 
efficiency was 95\%; thereafter, there was stable charge and discharge. Figure 5 shows a rate performance of $\mathrm{NaCrO}_{2}$ positive electrodes ${ }^{[19 c]}$. When the charge and discharge rate were changed to $20-500 \mathrm{~mA} \mathrm{~g}^{-1}$, a reduction in capacity was observed with a rate increase, but in practical terms we achieved adequately superior rate performance. After completing the $500-\mathrm{mA} \mathrm{g}^{-1}$ test, the discharge capacity obtained at $20 \mathrm{~mA} \mathrm{~g}^{-1}$ was almost the same as that of the first discharge, which suggests that there was no deterioration of the test cell during the rate test. At this time, the coulombic efficiency obtained by dividing the discharge capacity by the charge capacity was $99 \%$ or higher once we excluded a few cycles immediately after the rate change. Figure 6 shows the temperature dependence of the discharge capacity acquired when the test temperature was changed from $80^{\circ} \mathrm{C}$ to $-20^{\circ} \mathrm{C}$. We found that the discharge capacity significantly decreased at $0{ }^{\circ} \mathrm{C}$ and lower, but even for tests undertaken at $-20{ }^{\circ} \mathrm{C}$, an operating temperature envisioned for cold climates, charge and discharge was possible, despite the small discharge capacity. When we performed a test at $80{ }^{\circ} \mathrm{C}$ after the $-20^{\circ} \mathrm{C}$ test, the discharge capacity recovered to the initial level, as expected, which suggested that there was no marked deterioration. Also, at the low rate of $20 \mathrm{mAh} \mathrm{g} \mathrm{g}^{-1}$, almost the theoretical capacity was obtained at $90{ }^{\circ} \mathrm{C}$, which is clearly different from the discharge at $25^{\circ} \mathrm{C}$, suggesting that it may be possible to access capacity unavailable at room temperature by operating in the intermediate temperature range. The coulombic efficiency was 99\% or higher, apart from a few cycles immediately after the temperature change, and at $-20^{\circ} \mathrm{C}$. Based on the above data, we confirmed that $\mathrm{NaCrO}_{2}$ positive electrodes can operate over a wide temperature range of -20 to $80{ }^{\circ} \mathrm{C}$. Na/NVPC using $\mathrm{Na}[\mathrm{FSA}]\left[\mathrm{C}_{2} \mathrm{C}_{1}\right.$ im] [FSA] ionic liquid also exhibits reversible capacities of $100.8,78.1$, and $57.6 \mathrm{~mA} \mathrm{~h} \mathrm{~g}^{-1}$ at 298,263 , and $253 \mathrm{~K}$, respectively ${ }^{[26]}$

Figure 7 shows the charge and discharge curves of Na2FeP2O7 positive electrode at $90{ }^{\circ} \mathrm{C}$ using $\mathrm{Na}[\mathrm{FSA}]-\left[\mathrm{C}_{2} \mathrm{C}_{1} \mathrm{im}\right]$ [FSA] (30:70 molar ratio) as the ionic liquid electrolyte [20c]. $\mathrm{Na}_{2} \mathrm{FeP}_{2} \mathrm{O}_{7}$ is a positive electrode material with a theoretical capacity of $97 \mathrm{mAh} \mathrm{g}^{-1}$ in a 1-electron reaction, and it has a three-dimensional $\mathrm{Na}+$ diffusion path; thus, it is expected to exhibit high $\mathrm{Na}+$ mobility ${ }^{[28]}$. In this test, $\mathrm{Na}_{2} \mathrm{FeP}_{2} \mathrm{O}_{7}$ was synthesized under an argon atmosphere and then washed; the dried sample was used after removal of impurities. The cut-off potential was $2.0-4.0 \mathrm{~V}$, the current density was $10 \mathrm{~mA} \mathrm{~g}^{-1}$, and we achieved a discharge capacity almost exactly the same as the theoretical capacity at $90{ }^{\circ} \mathrm{C}$. The in situ X-ray diffraction measurements at $90{ }^{\circ} \mathrm{C}$ showed no new peaks or disappearance of peaks, but only peak shifts and intensity changes. Thus, we ascertained that solid solution formation associated with charge and discharge occurred even at this temperature, as indicated by previous tests at room temperature. Interestingly, when we compared the rate characteristics of imidazolium ( $\left.\mathrm{Na}[\mathrm{FSA}]-\left[\mathrm{C}_{2} \mathrm{C}_{1} \mathrm{im}\right][\mathrm{FSA}]\right)$ with those of a pyrrolidinium-based ionic liquid ( $\mathrm{Na}[\mathrm{FSA}]$ $\left[\mathrm{C}_{2} \mathrm{C}_{1}\right.$ pyrr] $\left.[\mathrm{FSA}]\right)$, the former had better rate characteristics. This suggests that differences in the $\mathrm{Na}+$ ionic conductivity or the cation structure have an effect on the reaction at the interface.

Figure 8 shows the rate characteristics of $\mathrm{Na}_{2} \mathrm{FeP}_{2} \mathrm{O}_{7}$ when the $\mathrm{Na}[\mathrm{FSA}]$ fraction was changed for a $\mathrm{Na}[\mathrm{FSA}]-\left[\mathrm{C}_{2} \mathrm{C}_{1}\right.$ im] [FSA]based ionic liquid at $90^{\circ} \mathrm{C}$. Under these experimental conditions, the rate characteristics tended to improve as the $\mathrm{Na}+$ fraction increased. At $50 \mathrm{~mol} \%$, the current densities were 4000, 8000, 20000 , and $40000 \mathrm{~mA} \mathrm{~g}^{-1}$ (loading mass: $-3 \mathrm{mg} \mathrm{cm}^{-2} ; 1 \mathrm{~A} \mathrm{~g}^{-1}=$ $3 \mathrm{~mA} \mathrm{~cm}$ ), respectively, with corresponding discharge

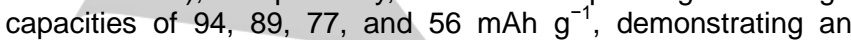
extremely favorable capacity retention rate. Figure 9 shows the results of an investigation into the cycle characteristics of a $\mathrm{Na}_{2} \mathrm{FeP}_{2} \mathrm{O}_{7}$ positive electrode with a current density of $1000 \mathrm{~mA}$ $\mathrm{g}^{-1}$ at $90{ }^{\circ} \mathrm{C}$. Under these conditions, $\mathrm{Na}_{2} \mathrm{FeP}_{2} \mathrm{O}_{7}$ positive electrodes demonstrated extremely high cycle characteristics; the capacity retention rate after 1500 cycles was $93 \%$, and the mean coulombic efficiency during the 1500 cycles was $99.9 \%$. Aluminum metal was used for the positive electrode current collector, but the low solubility of the film that forms on the aluminum surface in the ionic liquid is thought to play a part in the lack of deterioration in performance, even after repeated charge and discharge cycles.
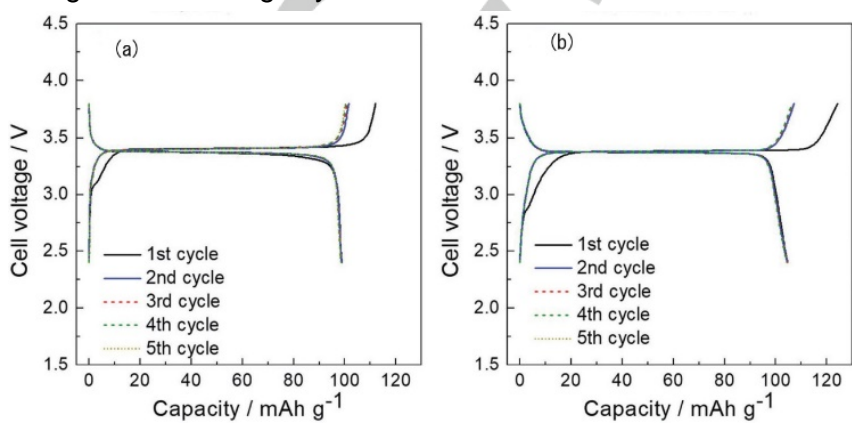

Figure 10 Charge-discharge curves of Na/NVPC cells at (a) $298 \mathrm{~K}$ and (b) 363 $\mathrm{K}^{[26]}$. Electrolyte: $\mathrm{Na}[\mathrm{FSA}]-\left[\mathrm{C}_{2} \mathrm{C}_{1} \mathrm{im}\right][\mathrm{FSA}]$ (50:50 in molar ratio). Chargedischarge rate: $0.1 \mathrm{C}$. Cutoff voltage: $2.4-3.8 \mathrm{~V}$.

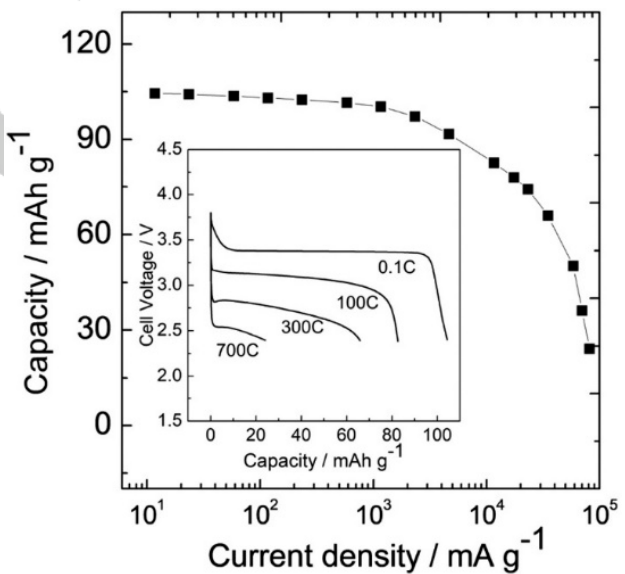

Figure $11 \mathrm{Na} / \mathrm{NVPC}$ cell rate capability at $363 \mathrm{~K}^{[26]}$. Electrolyte: $\mathrm{Na}[\mathrm{FSA}]$ $\left[\mathrm{C}_{2} \mathrm{C}_{1} \mathrm{im}\right][\mathrm{FSA}]$ (50:50 in molar ratio). Charge rate: $0.1 \mathrm{C}$. Discharge rates: $0.1 \mathrm{C}-700 \mathrm{C}$. Cutoff voltage: $2.4-3.8 \mathrm{~V}$.

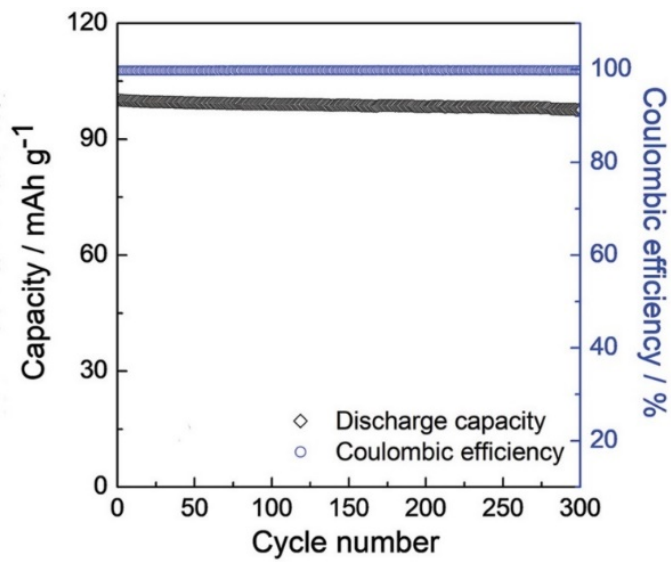

Figure 12 Cycling performance of an Na/NVPC cell at $363 \mathrm{~K}^{[26]}$. Electrolyte: $\mathrm{Na}[\mathrm{FSA}]-\left[\mathrm{C}_{2} \mathrm{C}_{1} \mathrm{im}\right][\mathrm{FSA}](50: 50$ in molar ratio). Charge rate: $0.1 \mathrm{C}$. Chargedischarge rates: $1 \mathrm{C}$. Cut-off voltages: $2.4-3.8 \mathrm{~V}$. 
Figure 10 shows galvanostatic charge-discharge curves of $\mathrm{Na} / \mathrm{NVPC}$ (NVPC: carbon-coated $\mathrm{Na}_{3} \mathrm{~V}_{2}\left(\mathrm{PO}_{4}\right)_{3}$ ) cells at $0.1 \mathrm{C}$ using the $\mathrm{Na}[\mathrm{FSA}]-\left[\mathrm{C}_{2} \mathrm{C}_{1}\right.$ im] [FSA] (50:50 in molar ratio) ionic liquid electrolyte. The NVPC composite exhibits reversible capacities of 98.7 and $104.5 \mathrm{~mA} \mathrm{~h} \mathrm{~g}^{-1}$ at $298 \mathrm{~K}$ (Figure 10a) and $363 \mathrm{~K}$ (Figure 10b), respectively. Carbon coating is essential to bring out the capacity from NVPC to overcome the inherent low electronic conductivity of NVP. During charge and discharge, a flat plateau was observed at $\approx 3.4 \mathrm{~V}$. This was associated with the $\mathrm{V4}^{+} / \mathrm{V}^{+}$redox activity $\left(\mathrm{NaV}_{2}\left(\mathrm{PO}_{4}\right)_{3} / \mathrm{Na}_{3} \mathrm{~V}_{2}\left(\mathrm{PO}_{4}\right)_{3}\right)$ seen in organic electrolytes ${ }^{[29]}$. Capacities of about $100 \mathrm{~mA} \mathrm{~h} \mathrm{~g}^{-1}$ were obtained at $298 \mathrm{~K}$ regardless of the $\mathrm{Na}[\mathrm{FSA}]$ mole fraction used. Figure 11 shows the results of rate capability tests of a Na/NVPC cell with the $\mathrm{Na}[\mathrm{FSA}]-\left[\mathrm{C}_{2} \mathrm{C}_{1}\right.$ im] $[\mathrm{FSA}]$ (50:50 in molar ratio) ionic liquid electrolyte at $363 \mathrm{~K}$. The cell was charged to $3.8 \mathrm{~V}$ at a constant current of $0.1 \mathrm{C}$ and then discharged to $2.4 \mathrm{~V}$ at currents ranging from $0.1 \mathrm{C}$ to $700 \mathrm{C}$. A discharge rate of $700 \mathrm{C}$ corresponds to $81900 \mathrm{~mA} \mathrm{~g}^{-1}$ and a full discharge in $5.1 \mathrm{~s}$. Up to a discharge rate of $100 \mathrm{C}$, the cells exhibited capacity retentions of at least $80 \%$ of the values achieved at $0.1 \mathrm{C}$. Moreover, capacity retentions of $48 \%, 35 \%$, and $23 \%$ were obtained at $500 \mathrm{C}, 600 \mathrm{C}$, and $700 \mathrm{C}$, respectively. Figure 12 shows the cycling performance of the $\mathrm{Na} / \mathrm{NVPC}$ cell in $\mathrm{Na}[\mathrm{FSA}]$ $\left[\mathrm{C}_{2} \mathrm{C}_{1}\right.$ im] $[\mathrm{FSA}]$ (50:50 in molar ratio). The NVPC electrode exhibited stable cycling performance at $363 \mathrm{~K}$. In addition, NVPC achieved outstanding capacity retention of $94.8-99.0 \%$ after 300 cycles and an average coulombic efficiency above $99.9 \%$. Such stable cycling performance is derived from the stable biphasic reaction between $\mathrm{NaV}_{2}\left(\mathrm{PO}_{4}\right)_{3}$ and $\mathrm{Na}_{3} \mathrm{~V}_{2}\left(\mathrm{PO}_{4}\right)_{3}$ and high durability of the ionic liquid against redox reactions including Al corrosion and oxidative decomposition ${ }^{[30]}$.

Metallic sodium as a negative electrode is the most idea from the view point of energy density, however, like the case of lithium, dendrite formation causes internal short circuit of the battery, which may sometimes evoke serious accidents. Sodium alloy or compound with a high capacity is necessary for a negative electrode of a rechargeable sodium battery. Negative electrodes such as hard carbon ${ }^{[31]}, \mathrm{Na}-\mathrm{Sn}$ alloys ${ }^{[32]}$, titanium oxide ${ }^{[33]}, \quad \mathrm{TiO}_{2}-\mathrm{Fe}_{2} \mathrm{O}_{3}$ nanocomposites ${ }^{[34]}$ have been investigated as negative electrode materials for sodium secondary batteries using FSA-based ionic liquids as electrolytes. In particular, carbon-coated $\mathrm{FeTiO}_{3}$ exhibited excellent cycleability over 2000 cycles at $1 \mathrm{C}$ rate without losing the initial capacity ${ }^{[35]}$

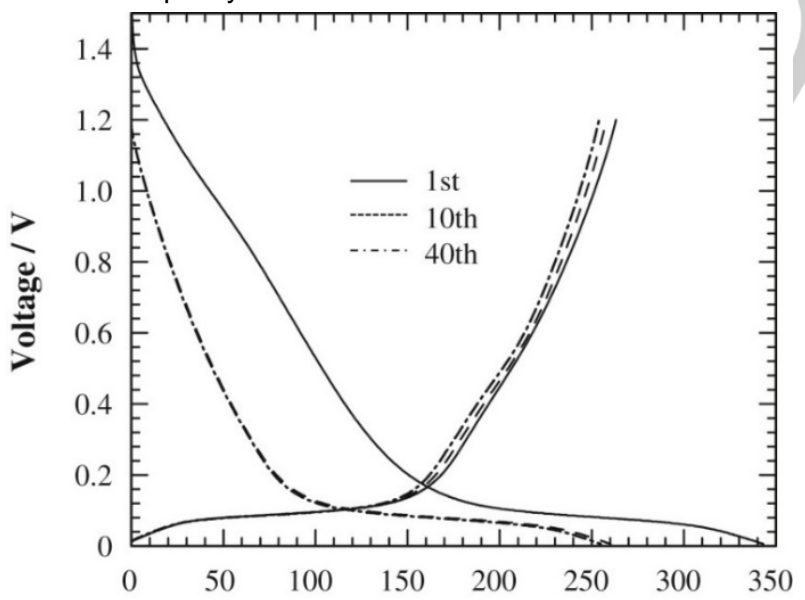

Capacity / mAh (g-HC) $)^{-1}$

Figure 13 Charge and discharge curves for a $\mathrm{Na} / \mathrm{NaFSA}-\mathrm{C}_{3} \mathrm{C}_{1}$ pyrFSA/HC cell at $363 \mathrm{~K}^{[31]}$. Charge-discharge rate: $50 \mathrm{~mA}(\mathrm{~g}-\mathrm{HC})^{-1}$; cut-off voltages: 0.005 and $1.200 \mathrm{~V}$; cycle number: $1 \mathrm{st}, 10 \mathrm{th}$, and 40 th.

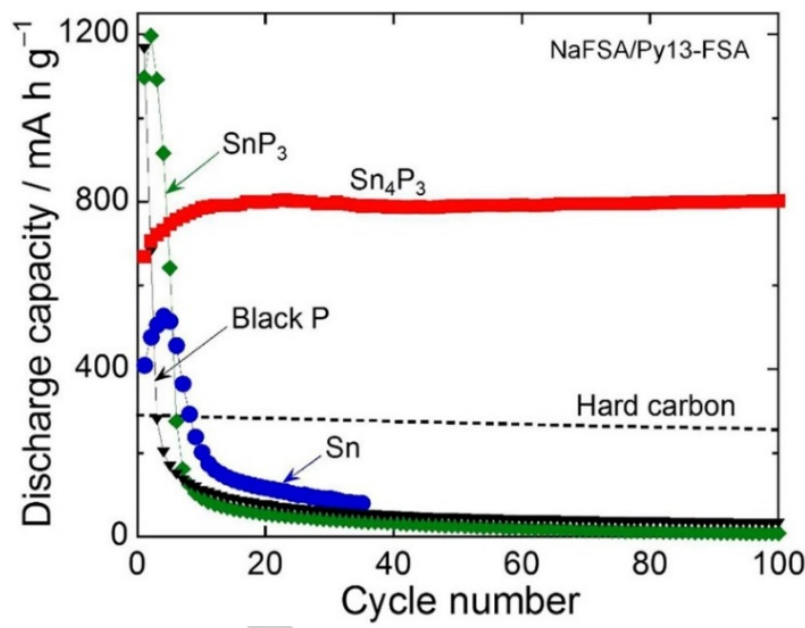

Figure 14 Cyclic performance of the $\mathrm{Sn}_{4} \mathrm{P}_{3}$ and $\mathrm{SnP}_{3}$ electrodes in an ionic liquid electrolyte of $\mathrm{NaFSA} / \mathrm{C}_{3} \mathrm{C}_{1} \mathrm{PyrFSA}^{[37]}$. For comparison, the capacities of the hard carbon electrode were also plotted.

Hard carbon was investigated as a negative electrode material ${ }^{[31]}$. The cell operated stably with a capacity of

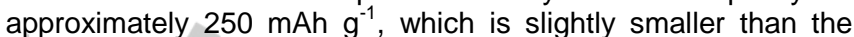
theoretical capacity (Figure 13). Sodium metal, which has the largest capacity, inhibited dendrite growth in an ionic liquid at $90{ }^{\circ} \mathrm{C}$, demonstrating a high deposition and dissolution efficiency; however, there have been problems with achieving stable operation, because the operating temperature is close to the melting point of sodium. On the other hand, alloy-based materials not only have theoretically large capacities, they are also very safe and can operate over a wide temperature range, which makes them attractive as negative electrode materials. For example, the Sn-Na alloy has a theoretical capacity of 847 mAh $\mathrm{g}^{-1}$ (when the state of charge is $\mathrm{Na}_{15} \mathrm{Sn}_{4}$ ) ${ }^{[4 a, 36]}$ and, although there are issues with the cycle characteristics, intermediate-temperature operation in ionic liquids is possible with this material ${ }^{[32]}$. Several phosphides have recently been found to exhibit excellent charge-discharge behavior in the FSAbased ionic liquid electrolyte. As shown in Figure 14, $\mathrm{Sn}_{4} \mathrm{P}_{3}$ has an extremely large capacity of approximately $800 \mathrm{mAh} \mathrm{g}^{-1}$ in ionic liquids, and shows stable operation for 200 or more cycles [37]. In $\mathrm{Sn}_{4} \mathrm{P}_{3}$, both $\mathrm{Sn}$ and $\mathrm{P}$ act as active mass and get charged to form amorphous nanocomposites of $\mathrm{Na}_{15} \mathrm{Sn}_{4}$ and $\mathrm{Na}_{3} \mathrm{P}$. On discharge, they are oxidized to a composite of $\mathrm{Sn}$ and $\mathrm{P}$ without forming the original alloy. $\mathrm{Sn}$ and its alloys with $\mathrm{Na}$ act as a conductive material to activate the poor electronic conductor, $\mathrm{P}$, leading to a high capacity and excellent cycleability. It has very recently been reported that $\mathrm{CuP}_{2}$ acts as a negative electrode material for $\mathrm{Na}$ batteries with a similar mechanism. Although the capacity is lower, $600 \mathrm{mAh} \mathrm{g}^{-1}$, with $\mathrm{Cu}$ acting only as a conductive additive, the composite exhibits excellent cycle and rate performance, especially at elevated temperatures of around $90^{\circ} \mathrm{C}^{[38]}$. 


\section{Full cell performance}

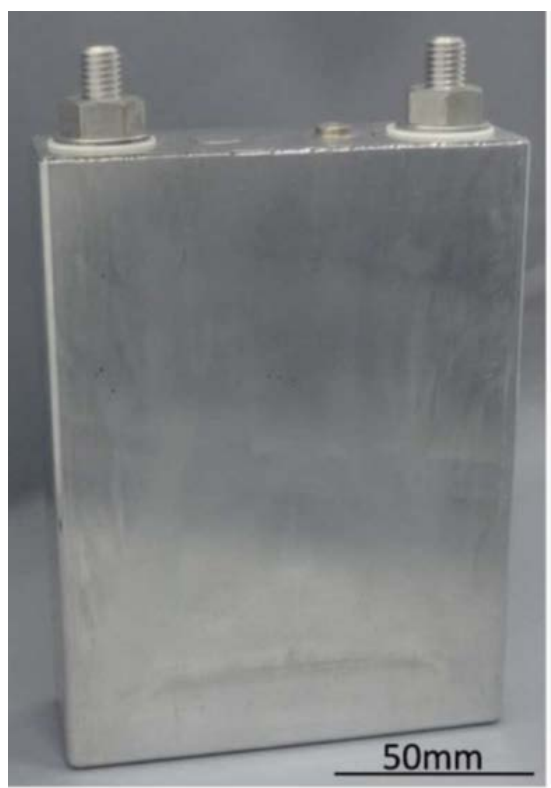

Figure 15 Appearance of a 27 Ah $\mathrm{HC} / \mathrm{Na}[\mathrm{FSA}]-\left[\mathrm{C}_{3} \mathrm{C}_{1}\right.$ pyrr][FSA]/NaCrO prismatic full cell ${ }^{[39]}$. External dimensions: $113 \times 150 \times 38 \mathrm{~mm}$. Weight: $1.08 \mathrm{~kg}$

Performances were evaluated for several types of full cells such as a prismatic cell, a 18650 cylindrical cell, and a pouch cell, using $\mathrm{NaCrO}_{2}$ and $\mathrm{HC}$ as the positive and negative electrode material, respectively. Here, a large-scaled practical sodium ion battery using ionic liquids developed by collaboration with Sumitomo Electric Industries is shown as an example. A hundred sets of laminated batteries using $\mathrm{NaCrO}_{2}$ as the positive electrode material and $\mathrm{HC}$ as the negative electrode material were piled and put in an aluminum canister. All the batteries were electrically connected in parallel by welding the lead tab. The ionic liquid electrolyte used for this battery was $\mathrm{Na}[\mathrm{FSA}]-\left[\mathrm{C}_{3} \mathrm{C}_{1}\right.$ pyrr] $[\mathrm{FSA}](20: 80)$. This prismatic battery shown in Figure 15 had a gravimetric energy density of $75 \mathrm{Wh} \mathrm{kg}^{-1}$ and volumetric energy density of $125 \mathrm{Wh} \mathrm{L}^{-1}{ }^{[39]}$. These values are comparable with those observed for large-scale prismatic lithium ion batteries used in the early 2000s. Figure 16 shows the charge-discharge curves for the 27-Ah $\mathrm{HC} / \mathrm{NaCrO}_{2}$ full cell at 298 and $333 \mathrm{~K}$. The observed discharge capacity at a rate of 2.7 A was $27.3 \mathrm{Ah}$ at $298 \mathrm{~K}$, which is equal to the designed capacity. At $333 \mathrm{~K}$, almost the same charge-discharge behavior was obtained, even at the higher rate of $10 \mathrm{~A}$. Figure 17 shows the rate dependence of the discharge capacity for the 27-Ah full cell at $283,298,313,333$, and $363 \mathrm{~K}$. On the other hand, the performance was unsatisfactory at $283 \mathrm{~K}$, which was due to the lower conductivity of the ionic liquid. Figure 18 shows the cycleability of the $27-\mathrm{Ah}$ full cell at a rate of $10 \mathrm{~A}$ at $333 \mathrm{~K}$. The capacity retention after 500 cycles was $87 \%$. It is the same value as that of large-scale prismatic lithium ion batteries used in the early 2000s. It should be emphasized that the 27-Ah cell was produced by an industrial process similar to that used for conventional lithium ion batteries. It is highly expected that a large-sized $\mathrm{HC} / \mathrm{Na}[\mathrm{FSA}]-\left[\mathrm{C}_{3} \mathrm{C}_{1}\right.$ pyrr] $[\mathrm{FSA}] / \mathrm{NaCrO}_{2}$ cell can show further improvements in the energy density, power density (rate capability), energy efficiency, and cycleability with the use of an improved manufacturing technology.

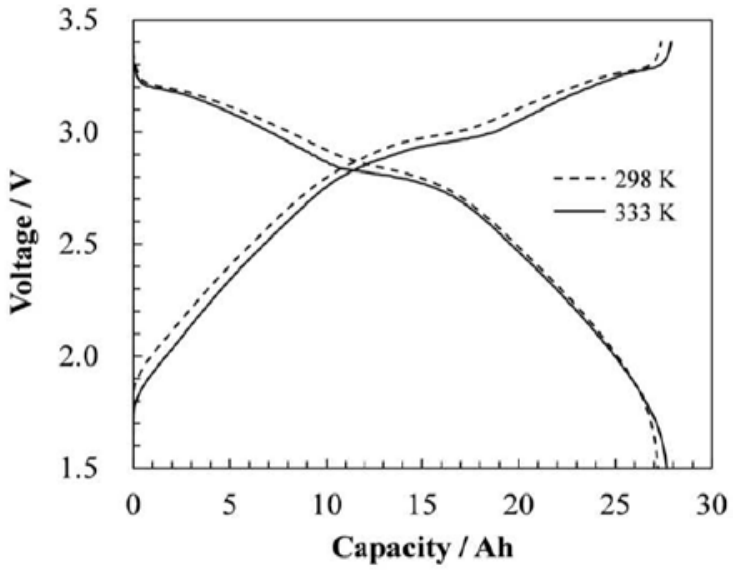

Figure 16 Charge-discharge curves for a 27 Ah HC/Na[FSA]$\left[\mathrm{C}_{3} \mathrm{C}_{1}\right.$ pyrr] $[\mathrm{FSA}] / \mathrm{NaCrO}_{2}$ full cell at 298 and $333 \mathrm{~K}{ }^{[39]}$. Charge-discharge rates: $2.7 \mathrm{~A}(298 \mathrm{~K})$ and $10 \mathrm{~A}(333 \mathrm{~K})$. Cut-off voltages: $1.5 \mathrm{~V}$ and $3.35 \mathrm{~V}$.

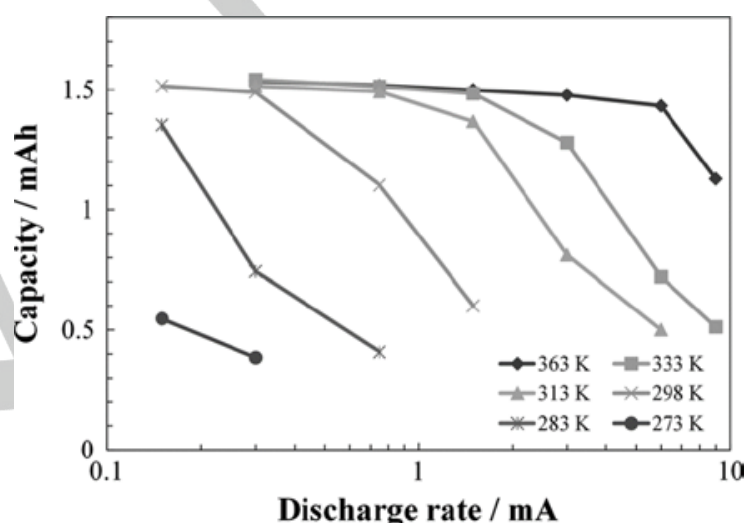

Figure 17 Rate dependence of the discharge capacity for a $1.5 \mathrm{mAh}$ $\mathrm{HC} / \mathrm{Na}[\mathrm{FSA}]-\left[\mathrm{C}_{3} \mathrm{C}_{1}\right.$ pyrr] [FSA]/ $\mathrm{NaCrO}_{2}$ full cell ${ }^{[39]}$. Charge conditions: $0.3 \mathrm{~mA}$ $\mathrm{CC}(313-363 \mathrm{~K})$ and $0.3 \mathrm{~mA} \mathrm{CC}-\mathrm{CV}$ (to $0.075 \mathrm{~mA}$ ) at $298 \mathrm{~K}(273-298 \mathrm{~K})$. Discharge rates: 0.15-9.0 mA. Operation temperatures: 273-363 K.

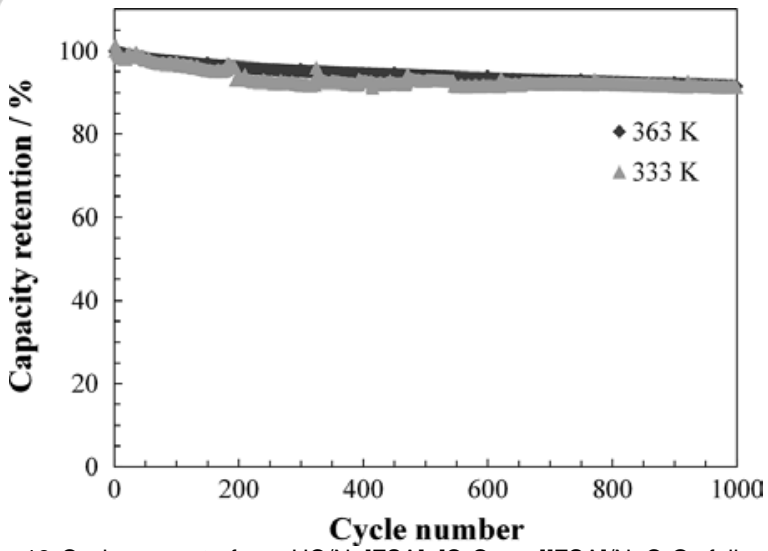

Figure 18 Cycle property for a $\mathrm{HC} / \mathrm{Na}[\mathrm{FSA}]-\left[\mathrm{C}_{3} \mathrm{C}_{1}\right.$ pyrr] $[\mathrm{FSA}] / \mathrm{NaCrO}_{2}$ full cell. Charge-discharge rate: $1.5 \mathrm{~mA}^{[39]}$. Operation temperatures: 363 and $333 \mathrm{~K}$ Cut-off voltages: 1.5 and $3.35 \mathrm{~V}$

\section{Conclusion}

With the increasing size of secondary batteries, sodium secondary batteries are attracting attention owing to the abundance of its constituent materials, compared with those of lithium secondary batteries. Moreover, when combined with ionic 
liquids, sodium secondary batteries can achieve an extended operating temperature range and improved safety, and therefore we can expect high-performance batteries to be developed with an expanded range of use. As shown in this paper, the operation of sodium secondary batteries at intermediate temperatures can enable the acquisition of properties unattainable at room temperature. Secondary batteries operable at intermediate temperatures have not previously attracted much attention, and so there is little awareness of the applications and superiority of their operation in this temperature range. With the spread of large secondary batteries, sodium secondary batteries that operate at intermediate temperatures using ionic liquid electrolytes are expected to be promising candidates. They are now chemical reagents rather than industrial raw materials. If the demands are significantly expanded for example by the mass production of large scaled power storage battery, the cost would be decreased. Especially the anion of our ionic liquids, FSA, does not need electrolytic fluorination process for synthesis unlike the case of TFSA, cost reduction for the production being envisaged. Such developments can lead to the application of ionic liquids as gel polymer electrolytes for sodium secondary batteries. ${ }^{[40]}$ In future, it will be essential to optimize the materials and the system. Future developments will require high energy density and low cost of the batteries, which makes it essential to search for high-capacity positive electrode materials using elements that are abundant, and it will also be necessary to understand the fundamental electrode reaction in the intermediate temperature range.

\section{Acknowledgements}

This study was partly supported by the Advanced Low Carbon Technology Research and Development Program (ALCA) of Japan Science and Technology Agency (JST) and the Japanese Ministry of Education Culture, Sports, Science, and Technology (MEXT) program "Elements Strategy Initiative to Form Core Research Center."

[1] a) B. Scrosati, J. Garche, J. Power Sources 2010, 195, 2419; b) B Dunn, H. Kamath, J. M. Tarascon, Science 2011, 334, 928; c) Z. G. Yang, J. L. Zhang, M. C. W. Kintner-Meyer, X. C. Lu, D. W. Choi, J. P. Lemmon, J. Liu, Chem. Rev. 2011, 111, 3577; d) B. L. Ellis, L. F. Nazar, Curr. Opin. Solid State Mater. Sci. 2012, 16, 168; e) K. Kubota, S. Komaba, J. Electrochem. Soc. 2015, 162, A2538; f) D. Larcher, J. M. Tarascon, Nature Chemistry 2015, 7, 19; g) J. W. Choi, D. Aurbach Nature Reviews Materials 2016, 1; h) X. Lin, M. Salari, L. M. Arava, P. M. Ajayan, M. W. Grinstaff, Chem. Soc. Rev. 2016, 45, 5848; i) L. Chen, M. Fiore, J. E. Wang, R. Ruffo, D. K. Kim, G. Longoni, Advanced Sustainable Systems 2018, 2, 1700153

[2] a) V. Palomares, M. Casas-Cabanas, E. Castillo-Martinez, M. H. Han, T. Rojo, Energy \& Environmental Science 2013, 6, 2312; b) Q. Li, J. Chen, L. Fan, X. Kong, Y. Lu, Green Energy \& Environment 2016, 1, 18.

[3] J. M. Tarascon, Nature Chemistry 2010, 2, 510.

[4] a) M. D. Slater, D. Kim, E. Lee, C. S. Johnson, Adv. Funct. Mater. 2013, 23, 947; b) N. Yabuuchi, K. Kubota, M. Dahbi, S. Komaba, Chem. Rev 2014, 114, 11636; c) A. Yamada, MRS Bull. 2014, 39, 423; d) D. Larcher, J. M. Tarascon, Nat Chem 2015, 7, 19; e) J.-Y. Hwang, S.-T. Myung, Y.-K. Sun, Chem. Soc. Rev. 2017, 46, 3529.

[5] a) K.M. Abraham, Solid State Ionics 1982, 7, 199. b) A. Ponrouch, R. Dedryvere, D. Monti, A. E. Demet, J. M. A. Mba, L. Croguennec, C. Masquelier, P. Johansson, M. R. Palacin, Energy \& Environmental Science 2013, 6, 2361.

[6] A. Ponrouch, D. Monti, A. Boschin, B. Steen, P. Johansson, M. R. Palacin, Journal of Materials Chemistry A 2015, 3, 22.
[7] G. G. Eshetu, S. Grugeon, S. Laruelle, S. Boyanov, A. Lecocq, J.-P Bertrand, G. Marlair, PCCP 2013, 15, 9145.

[8] a) S. M. Lukic, J. Cao, R. C. Bansal, F. Rodriguez, A. Emadi, IEEE Transactions on Industrial Electronics 2008, 55, 2258; b) H. Chen, T. N Cong, W. Yang, C. Tan, Y. Li, Y. Ding, Progress in Natural Science 2009, 19, 291; c) K. C. Divya, J. Østergaard, Electric Power Systems Research 2009, 79, 511; d) E. Karden, S. Ploumen, B. Fricke, T. Miller, K. Snyder, J. Power Sources 2007, 168, 2; e) S. Vazquez, S. M. Lukic E. Galvan, L. G. Franquelo, J. M. Carrasco, IEEE Transactions on Industrial Electronics 2010, 57, 3881; f) M. R. Palacin, Chem. Soc. Rev. 2009, 38, 2565; g) G. L. Soloveichik, Annu Rev Chem Biomol Eng 2011, $2,503$.

[9] a) J. P. Hallett, T. Welton, Chem. Rev. 2011, 111, 3508; b) T. Torimoto T. Tsuda, K. Okazaki, S. Kuwabata, Adv. Mater. 2010, 22, 1196; c) B Andrew, H. Matthias, M. Faezeh, P. G. Cristina, M. D. R., H. P. C., F. Maria, Advanced Energy Materials 0, 1703491.

[10] H. Ohno, Electrochemical Aspects of Ionic Liquids, John Wiley \& Sons Inc., Hoboken, New Jersey 2011.

[11] a) M. Armand, F. Endres, D. R. MacFarlane, H. Ohno, B. Scrosati Nature Materials 2009, 8, 621; b) D. R. MacFarlane, N. Tachikawa, M. Forsyth, J. M. Pringle, P. C. Howlett, G. D. Elliott, J. H. Davis, M Watanabe, P. Simon, C. A. Angell, Energy Environ. Sci. 2014, 7, 232.

[12] a) K. Matsumoto, Y. Okamoto, T. Nohira, R. Hagiwara, Journal of Physical Chemistry C 2015, 119, 7648; b) K. Matsumoto, T. Hosokawa T. Nohira, R. Hagiwara, A. Fukunaga, K. Numata, E. Itani, S. Sakai, K. Nitta, S. Inazawa, J. Power Sources 2014, 265, 36; c) K. Matsumoto, R Taniki, T. Nohira, R. Hagiwara, J. Electrochem. Soc. 2015, 162, A1409.

[13] K. Kuratani, N. Uemura, H. Senoh, H. T. Takeshita, T. Kiyobayashi, J. Power Sources 2013, 223, 175.

[14] a) H. Vogel, Physikalische Zeitschrift 1921, 22, 645; b) G. S. Fulcher, J. Am. Ceram. Soc. 1925, 8, 339; c) W. Xu, E. I. Cooper, C. A. Angell, J. Phys. Chem. B 2003, 107, 6170; d) A. Noda, K. Hayamizu, M. Watanabe, J. Phys. Chem. B 2001, 105, 4603.

[15] a) M. Ishikawa, T. Sugimoto, M. Kikuta, E. Ishiko, M. Kono, J. Power Sources 2006, 162, 658; b) H. Matsumoto, H. Sakaebe, K. Tatsumi, M. Kikuta, E. Ishiko, M. Kono, J. Power Sources 2006, 160, 1308.

[16] T. Hosokawa, K. Matsumoto, T. Nohira, R. Hagiwara, A. Fukunaga, S. Sakai, K. Nitta, J. Phys. Chem. C 2016, 120, 9628.

[17] I. A. Shkrob, T. W. Marin, Y. Zhu, D. P. Abraham, J. Phys. Chem. C $2014,118,19661$

[18] K. Kubota, T. Nohira, R. Hagiwara, J. Chem. Eng. Data 2010, 55, 3142

[19] a) A. Fukunaga, T. Nohira, Y. Kozawa, R. Hagiwara, S. Sakai, K. Nitta S. Inazawa, J. Power Sources 2012, 209, 52; b) C. Y. Chen, K Matsumoto, T. Nohira, R. Hagiwara, A. Fukunaga, S. Sakai, K. Nitta, S Inazawa, J. Power Sources 2013, 237, 52; c) C. S. Ding, T. Nohira, K Kuroda, R. Hagiwara, A. Fukunaga, S. Sakai, K. Nitta, S. Inazawa, J. Power Sources 2013, 238, 296; d) C. S. Ding, T. Nohira, R. Hagiwara K. Matsumoto, Y. Okamoto, A. Fukunaga, S. Sakai, K. Nitta, S Inazawa, J. Power Sources 2014, 269, 124

[20] a) C. Y. Chen, K. Matsumoto, T. Nohira, C. S. Ding, T. Yamamoto, R. Hagiwara, Electrochim. Acta 2014, 133, 583; b) C. Y. Chen, K. Matsumoto, T. Nohira, R. Hagiwara, Y. Orikasa, Y. Uchimoto, J. Power Sources 2014, 246, 783; c) C. Y. Chen, T. Kiko, T. Hosokawa, K Matsumoto, T. Nohira, R. Hagiwara, J. Power Sources 2016, 332, 51.

[21] C. Y. Chen, K. Matsumoto, T. Nohira, R. Hagiwara, J. Electrochem. Soc. 2015, 162, A176

[22] C. Y. Chen, K. Matsumoto, T. Nohira, R. Hagiwara, J. Electrochem. Soc. 2015, 162, A2093.

[23] C. Y. Chen, K. Matsumoto, T. Nohira, R. Hagiwara, Electrochem. Commun. 2014, 45, 63.

[24] C. Ding, T. Nohira, R. Hagiwara, Electrochim. Acta 2017, 231, 412

[25] a) J. Hwang, K. Matsumoto, T. Nohira, R. Hagiwara, Electrochemistry 2017, 85, 675; b) J. Hwang, K. Matsumoto, Y. Orikasa, M. Katayama, Y. Inada, T. Nohira, R. Hagiwara, J. Power Sources 2018, 377, 80. 
[26] J. Hwang, K. Matsumoto, R. Hagiwara, Advanced Sustainable Systems 2018, 2, 1700171.

[27] a) C. Delmas, C. Fouassier, P. Hagenmuller, Physica B \& C 1980, 99 81 ; b) S. Komaba, C. Takei, T. Nakayama, A. Ogata, N. Yabuuchi, Electrochem. Commun. 2010, 12, 355. c) S. Komaba, T. Nakayama, A Ogata, T. Shimizu, C. Takei, S. Takada, A. Hokura, I. Nakai, ECS Trans. 2009, 16, 43

[28] a) P. Barpanda, T. Ye, S. Nishimura, S. C. Chung, Y. Yamada, M. Okubo, H. S. Zhou, A. Yamada, Electrochem. Commun. 2012, 24, 116 b) T. Honma, T. Togashi, N. Ito, T. Komatsu, J Ceram Soc Jpn 2012, 120, 344.

[29] K. Saravanan, C. W. Mason, A. Rudola, K. H. Wong, P. Balaya, Adv. Energy. Mater. 2013, 3, 444.

[30] a) C. Verma, E. E. Ebenso, M. A. Quraishi, J. Mol. Liq. 2017, 233, 403; b) E. Cho, J. Mun, O. B. Chae, O. M. Kwon, H. T. Kim, J. H. Ryu, Y. G. Kim, S. M. Oh, Electrochem. Commun. 2012, 22, 1.

[31] A. Fukunaga, T. Nohira, R. Hagiwara, K. Numata, E. Itani, S. Sakai, K. Nitta, S. Inazawa, J. Power Sources 2014, 246, 387.

[32] a) T. Yamamoto, T. Nohira, R. Hagiwara, A. Fukunaga, S. Sakai, K. Nitta, S. Inazawa, J. Power Sources 2012, 217, 479; b) T. Yamamoto, T. Nohira, R. Hagiwara, A. Fukunaga, S. Sakai, K. Nitta, S. Inazawa, J. Power Sources 2013, 237, 98.

[33] a) C. Ding, T. Nohira, R. Hagiwara, J Mater Chem A 2015, 3, 20767; b) C. Ding, T. Nohira, R. Hagiwara, Phys. Chem. Chem. Phys. 2016, 18 30770.

[34] C. S. Ding, T. Nohira, R. Hagiwara, Sustainable Energy \& Fuels 2017, $1,371$.

[35] C. Ding, T. Nohira, R. Hagiwara, J. Power Sources 2018, 388, 19

[36] V. L. Chevrier, G. Ceder, J. Electrochem. Soc. 2011, 158, A1011.

[37] H. Usui, Y. Domi, K. Fujiwara, M. Shimizu, T. Yamamoto, T. Nohira, R. Hagiwara, H. Sakaguchi, Acs Energy Letters 2017, 2, 1139.

[38] S. Kaushik, J. Hwang, K. Matsumoto, Y. Sato, R. Hagiwara, Chemelectrochem 2018, 5, 1340.

[39] A. Fukunaga, T. Nohira, R. Hagiwara, K. Numata, E. Itani, S. Sakai, K. Nitta, J. Appl. Electrochem. 2016, 46, 487.

[40] a) A. Boschin, P. Johansson, Electrochim. Acta 2016, 211, 1006; b) V. K. Singh, S. Shalu, S. K. Chaurasia, R. K. Singh, RSC Adv. 2016, 6, 40199; c) M. A. Ab Rani, J. Hwang, K. Matsumoto, R. Hagiwara, J. Electrochem. Soc. 2017, 164, H5031. 


\section{Entry for the Table of Contents}

\section{PERSONAL ACCOUNT}

The present review focuses on sodium ion batteries using binary systems of sodium and quaternary ammonium salts as electrolytes. A series of electrode materials were prepared, and examined to be combined with ionic liquid electrolytes. Sodium ion batteries using ionic liquids exhibited great performance and improved the safety of the batteries remarkably in a wide temperature range.

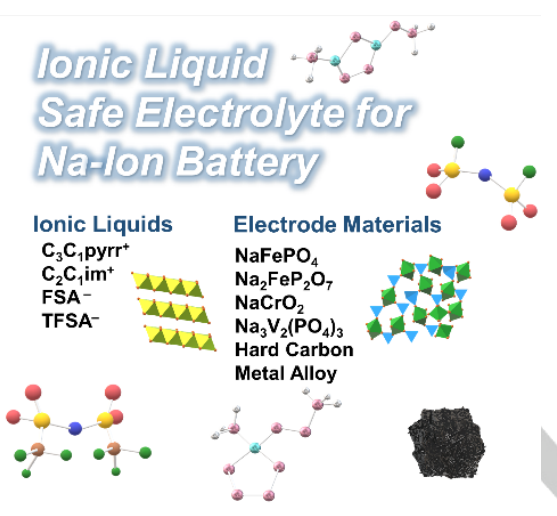

Rika Hagiwara*, Kazuhiko Matsumoto, Jinkwang Hwang, Toshiyuki Nohira

Page No. - Page No.

Sodium ion batteries using ionic liquids as electrolytes 